\title{
EMPLOYMENT EMPOWERING WOMEN: AN EXPERIENCE OF NEPAL
}

\author{
Bandana Kumari Jain \\ Lecturer, Post-Graduate Campus, Biratnagar, TU. \\ Corresponding author: bandana.jain@pgc.tu.edu.np
}

\begin{abstract}
The study aims to examine the association between employment and the empowerment of Nepali currently married women. It harnesses women's employment status and their empowerment; in terms of 'household decision making', 'attitudes towards wife-beating', and ownership of the house/land' with the help of the Nepal Demographic and Health Survey (NDHS) 2016 data set. Married women's employment exhibits a significant association (0.05) with their socio-demographic characteristics, and empowerment variables as well. The employment status of married women influences their household decisionmaking, and attitudes towards wife-beating. The study adheres to the belief that employment accelerates women's empowerment, still, it is complex to determine the strength of the relationship in between. Thus, based on the findings of the study, other variables and empowerment indicators are to be considered and analyzed further for concrete insights. So, employment cannot be assumed as a mere engine and an only instrument for empowering women.
\end{abstract}

Keywords: married women - empowerment - employment - household decisionmaking - attitudes towards wife-beating.

\section{BACKGROUND}

The longer involvement of the women in agricultural activities with no economic return is placing them in a secondary position which drags women's overall situation to worse (Berniell \& Sánchez-Páramo 2011). Women's access to economic resources is inevitable to expand economic growth, promote social development and enhance business performance (Batliwala 1994, Malhotra \& Schuler 2005) hence World Bank admits economic access as a prerequisite for sustainable development and inclusive growth. Labour economists analyze gender-specific differences in education, skills, and experiences rooted in society is limiting the productive role of 
women which follows the unequal distribution of employment additionally raw skills, low pays and vulnerable work conditions. It augments power imbalance, consequently exacerbates women's empowerment (Braunstein 2008).

Though women's employment is indispensable for unlocking future growth especially in developing and emerging countries (IFC 2013), it is still overlooked and under-appreciated (IFC 2013) by concerning agencies. The prevailing and rocentric system confines women's positive interference in the decision-making process, in settling the complexities of the economy, and in sharing the workplace by women (Duflo 2012). However, feminists are consistently defending such change in the conventional economic system to reconcile women to mainstream (Duflo 2012).

The advocacy of women's economic empowerment is one of the fundamental building blocks in the way of empowerment (UNESCAP 1999) which fosters women's employment to reduce poorly paid or unpaid work. Concurrently, empowerment minimizes the vulnerable and informal work of women with afforded security. By and large, this boosts women's access to decision-making, freedom of mobility, and control over productive resources. In this connection, various studies witness households enjoying more equality have a lower risk of family malnutrition and a higher probability of educating daughters (Phan 2015).

Identically, the Asia Foundation (2009) states Nepal is one of the least-developed countries in the world and experiences mediocre autonomy and little control over prolific assets to women. High rates of poverty and some rotten culture multiply unequal access to food and education among gender which limits the opportunities for Nepali women (Acharya et al. 2010). Women's participation in economic activities can be one of the strongest strategies among myriad poverty reduction instruments. Increasing women's economic opportunities and investing in women elusively stimulates their lives and subsequently, as shown by the Asia Foundation (2009) and other empirical studies, empowers women who contribute to the livelihood of their dependents (Acharya et al. 2010). Thus, the study aims to determine the relationship between employment and women's empowerment.

\section{OBJECTIVES OF THE STUDY}

Specifically, the study intends to measure the relationship between the employment and empowerment of women. The objectives of the study are; 


\section{EMPLOYMENT EMPOWERING WOMEN: AN EXPERIENCE OF NEPAL}

1. To measure the relationship between the employment and empowerment of women.

2. To examine the association of empowerment with personal demographic characteristics (age, education, province, types of residence, currently working status, and wealth index).

\section{LITERATURE REVIEW}

Empowerment is still a debatable issue on its meaning and measurement, highlights individual and collective aspects of power (Calves 2009). However, Kishor (2000) advocates empowerment is an agency and process as well where the agency stands for measuring women's curb over their resources (Batliwala 1995, Rowland 1997, White \& Killick 2001) and process stands for existence or absence of workable setting and access to seedbed for empowerment. Some intergovernmental and non-governmental organizations argue empowerment as choices in the hands and control over women's life (UNDP, UNFPA) then SIDA enlarges empowerment to choices offered to them.

Besides, empowerment is generating consciousness (Bisnath, 2001) in terms of opportunities and the ability to act (Mueller, 1998). Alike, Kabeer (2005) defines empowerment as the power within, power to, power over, and power with and condemns for openness for strategic life choices (Kabeer 2005). Rowland (1997) asserts differently that empowerment is a process (Batliwala 1995) to challenge and eliminate women's subordination (Batliwala 1995, Mason \& Smith 2003). Empowerment is to organize women to enhance their self-reliance in terms of mobility (Jejeebhoy 2002), to combat making independent choices. Further, access to knowledge and participation in communities (White \& Killick 2001), say in family size decision (Mason \& Smith 2003), and access to economic resources (Jejeebhoy 2002) are also covered as measures of women's empowerment. Besides, Bisnath (2001) incorporates political mobilization of women for their genuine empowerment.

UN Women and NRNA (2014) believe that societies could empower women and taste equality if women have opportunities to participate, contribute and lead all sectors. Indeed, women at work mean beyond immediate survival needed rather it has proved for visible changes in the families and societies (Phan 2015), to reduce poverty with economic growth remarkably in China, India, Vietnam (OECD 2012). 
The literature propels that the economic involvement of women is a reservation of empowerment. Some condemn for positive effects of women's working on their household decision-making (Acharya et al. 2010, Alam et al. 2018, Pambè \& Thiombiano 2014, West, 2006, Atteraya et al. 2016; Hanmer \& Klugman 2016, Phan 2015), attitude towards wifebeating (Alam et al. 2018, Diallo \& Ã 2016, Hanmer \& Klugman 2016) and ownership of house/land (Basnet 2014, Mishra \& Sam 2016, Atteraya et al. 2016). Therefore, the study attempts to measure the relationship between gainful activities involvement and empowerment of women.

\section{CONCEPTUAL FRAMEWORK}

The study is based on the following conceptual framework.

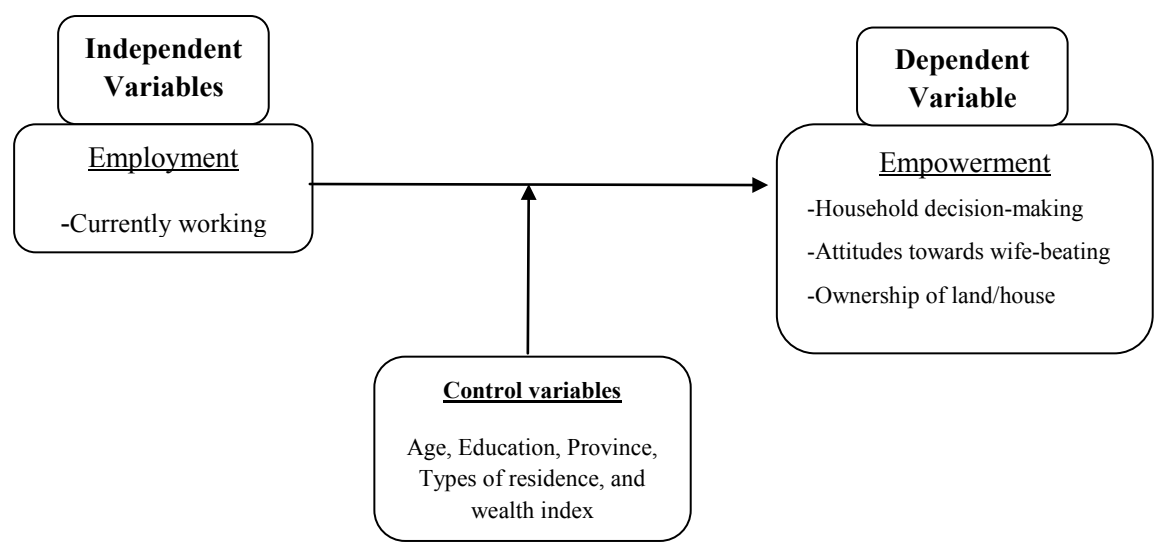

Figure 1: Conceptual framework

Empowerment, the dependent variable is measured on the three indicators namely household decision-making, attitudes towards wife-beating, and ownership of land/house. Employment represents an independent variable and age, education, province, types of residence, and wealth index are control variables. The empowerment of married women depends on their working status. The association of empowerment and socio-demographics of women is also measured.

\section{DATA AND METHODOLOGY}

The current study is based on secondary data from the Nepal Demographic and Health Survey (NDHS) 2016, a nationally representative population-based household sample survey. Detailed information about 
sampling design, sampling frame, the data collection procedure is described in NDHS, 2016.

The descriptive and causal-comparative research design was implied for the study. This study used only data from women's questionnaires since the focus was on women's employment and their empowerment. The variables and codes of variables (in parentheses) were the same from NDHS data and represented the same in this study. The current study dropped the observations with missing information for the variables included in the analysis, hence it is limited to a currently married woman which reduced the sample size to 9897 women. The study had harnessed Pearson's chisquare, Cramer's V, and logistic regression for the analysis of data to derive some results and conclusions.

\section{Dependent variable: Empowerment}

Empowerment is operationalized by many variables that serve as indicators of empowerment. The study had chosen household decisionmaking, attitudes towards wife-beating, and ownership of land/house as indicators of women's empowerment.

Household Decision-Making: Household decision-making was based on three variables; (1) person who usually decides on respondent's health care (V743A), 2) person who usually decides on large household purchases (V743B), and 3) a person who usually decides on visits to family or relatives (V743D), from NDHS in this study. Each question had six responses: 1) respondent only;2) respondent and husband/partner; 3) respondent and other people; 4) husband/partner alone; 5) someone else, and 6) others. To create a binary variable for the analysis, this study accepted respondent only, respondent and husband/partner, and respondent and other person responses as high empowered (1) and rest responses as low empowered (0). In the Asian context, people have the robust bond of togetherness hence most of the issues in houses are dealt with by husband and wife together that's why the involvement of women in decision-making is also assumed to be empowered (Acharya \& Bennette 1983, Acharya et al. 2010, Chowdhury et al. 2018).

The internal consistency among these three variables of decisionmaking was 0.799 (Cronbach $\alpha=0.799$ ). A decision-making scale is created by finding a mean score for each respondent across three decision-making variables. Scores ranged from 0 to 1 with a higher score (1) corresponded to greater and lower score $(0)$ represented weak levels of decision making. 
Attitudes towards wife-beating: Attitudes towards wife-beating was another indicator of empowerment. Currently married $(n=9897)$ were asked a fiveset of questions; 1. Beating justified if the wife goes out without telling husband (V744A); 2. Beating justified if the wife neglects the children (V744B); 3. Beating justified if wife argues with husband (V744C); 4. Beating justified if the wife refuses to have sex with husband (V744D); and 5. Beating is justified if the wife burns the food (V744E). The mutually exclusive responses for these questions are 'yes' or 'no' or 'do not know'. The respondents denying the given questions; for measuring attitudes towards the wife-beating, assumed to be high on empowerment and rest were probe as low empowerment attitude for wife-beating.

The reliability of these five variables was 0.537 (Cronbach $\alpha=$ 0.537 ), and after deleting two items namely beating justified if the wife refuses to have sex with the husband (V744D) and beating justified if the wife burns the food, Cronbach $\alpha$ becomes 0.551. Alam et al., (2018) had Cronbach $\alpha=0.77$ for all five items. Mean score for all married women on the remaining set of three questions created for attitudes towards wifebeating scale which ranged from 0 to 1 where women who disagreed on all three questions were assumed to be highly empowered (1) and otherwise were as less empowered (0).

Ownership of land/house: Ownership of land/house was the third indicator of empowerment. Two questions regarding ownership of land first owning a house alone or jointly (V745A) and second owning land alone or jointly (V745B) extracted from data NDHS 2016. The responses were 'does not have', 'alone only', 'jointly', and 'both alone and jointly. According to these responses the very first reply (does not have) is considered as less empowered (0) and remaining all (alone only, jointly only, and both joint and alone) corresponding to high empowered (1). The internal consistency of the two variables was Cronbach $\alpha=0.561$. The ownership of land/house scale promulgated by adding the answers on two questions subsequently the responses scoring 1 or more (ownership of either house or land or both) assumed to be high empowered (1) and remaining as (0) low empowered by ownership of house/land.

\section{Independent variable: Employment}

The research tested the relationship between employment and the empowerment of women. Employment was an independent variable, measured with a woman respondent's currently working status (V714) by 


\section{EMPLOYMENT EMPOWERING WOMEN: AN EXPERIENCE OF NEPAL}

NDHS 2016. The variable currently working subsequently partitioned into whether or not respondents currently working.

\section{Control variables: Socio-demographic characteristics}

In addition to the employment variable, a few key sociodemographic characteristics age, education, province, types of residence, and wealth index were included as control variables.

\section{RESULTS}

The relationship in between employment and empowerment and association with personal characteristics were analyzed below;

Table 1: Currently working and not working married women by characteristics $(n=9897)$

\begin{tabular}{|c|c|c|c|c|}
\hline Variables & Category & Not Working & Working & Total \\
\hline \multirow[t]{3}{*}{ Age } & Up to 20 & 53.8 & 46.2 & 1388 \\
\hline & $21-35$ & 40.8 & 59.2 & 5070 \\
\hline & $36-49$ & 31.3 & 68.7 & 3439 \\
\hline \multicolumn{5}{|c|}{ Chi-square $=219.760 * * * \quad$ Cramer's V $=0.149 * * *$} \\
\hline \multirow[t]{4}{*}{ Education } & No education & 35.6 & 64.4 & 4049 \\
\hline & Primary & 38.3 & 61.7 & 1810 \\
\hline & Secondary & 43.9 & 56.1 & 2936 \\
\hline & Higher & 42.1 & 57.9 & 1102 \\
\hline \multicolumn{5}{|c|}{ Chi-square $=53.860 * * * \quad$ Cramer's V $=0.074 * * *$} \\
\hline \multirow[t]{5}{*}{ Wealth } & Poorest & 25.2 & 74.8 & 2110 \\
\hline & Poorer & 30.6 & 69.4 & 2085 \\
\hline & Middle & 42.1 & 57.9 & 2058 \\
\hline & Richer & 47.8 & 52.2 & 1960 \\
\hline & Richest & 54.5 & 45.5 & 1684 \\
\hline \multicolumn{5}{|c|}{ Chi-square $=468.441 * * * \quad$ Cramer's $V=0.218 * * *$} \\
\hline \multirow[t]{7}{*}{ Province } & Province1 & 41.2 & 58.8 & 1396 \\
\hline & Province2 & 60.3 & 39.7 & 1754 \\
\hline & Province 3 & 31.8 & 68.2 & 1171 \\
\hline & Province4 & 32.9 & 67.1 & 1214 \\
\hline & Province5 & 38 & 62.0 & 1585 \\
\hline & Province6 & 33.8 & 66.2 & 1419 \\
\hline & Province 7 & 29.7 & 70.3 & 1358 \\
\hline \multicolumn{5}{|c|}{ Chi-square $=444.864 * * *$ Cramer's $V=0.212 * * *$} \\
\hline Types of & Urban & 41.4 & 58.6 & 6259 \\
\hline residence & Rural & 35.7 & 64.3 & 3638 \\
\hline Chi-square $=32$ & $2.185 * * *$ Cram & $r ' s \mathrm{~V}=0.057 * * *$ & & \\
\hline
\end{tabular}

Source: calculated from NDHS, 2016

Note: * indicates $p<0.05, * *$ indicates $p<0.01$ and $* * *$ indicates $p<0.001$ 
Table 1 depicts married women of older age are more involved in working activities. Women who never attended school are more likely to be employed than other academic levels. Surprisingly, as the education level goes up women's employment falls. Interestingly, women belonging to higher strata of wealth index fall on working status. Province 5, 6, and 7 are comparatively found to be sound on the working status of married women whereas province 2 is very low on women's employment. Comparatively, rural women are found to be more at work than urban women. Pearson chisquare $\left(0.001^{* * *}\right)$ for all socio-demographic characteristics under study depict statistically significant association with currently working women but have a weak relation.

Table 2 converses that married women earn household decisionmaking and ownership of house/land by their growing age and the association is statistically significant too. Higher education of women leads to their unfavourable attitudes towards wife-beating and ownership of the house/land. Working women with higher education are more likely to be conscious of their health. Except for 'ownership of house alone or jointly' all other variables of empowerment are associated with education, remarkably the association is weak as demonstrated by Cramer's V.

The percentage of empowered married women on all the three variables of household decision making and similarly three variables of justifying wife-beating is higher for working women. Working married women are more likely to be empowered to decide on the major household purchase and negate justifying wife-beating. Working status is associated with the respective three variables of household decision making and justifying wife-beating as well. According to Cramer's V, the association is weak ( $V$ is less than 0.20 ) for all the variables. A minimal number of women have ownership of house/land in Nepal. It means that meager women are high empowered in case of ownership of land/house. Among these limited numbers, who have ownership of land or house, more are of not working status though it cannot be overlooked that the percentage of not working owner of house/land women is remarkably low. There is an association in ownership of house/land and women's employment status as the p-value (0.047) is significant but the relation is tender. 


\section{EMPLOYMENT EMPOWERING WOMEN: AN EXPERIENCE OF NEPAL}

Table 2: Summary statistics of predictor variables for the empowerment of currently married women with their socio-demographic characteristics $(\mathrm{N}$ =9897)

\begin{tabular}{|c|c|c|c|c|c|c|c|c|}
\hline \multirow[b]{2}{*}{$\begin{array}{c}\text { Independent } \\
\text { variables }\end{array}$} & \multicolumn{3}{|c|}{ Household decision-making } & \multicolumn{3}{|c|}{ Justification for wife-beating } & \multicolumn{2}{|c|}{$\begin{array}{c}\text { Ownership of } \\
\text { house/land }\end{array}$} \\
\hline & 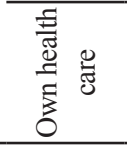 & 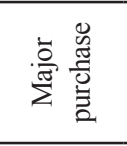 & 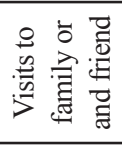 & 岕 & 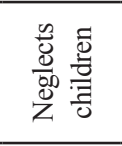 & 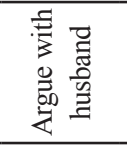 & 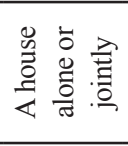 & 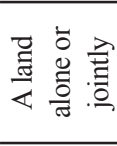 \\
\hline \multicolumn{9}{|l|}{ Age } \\
\hline Up to 20 & 31.8 & 17.9 & 21.8 & 88.5 & 73.8 & 90.7 & 1.0 & 1.2 \\
\hline 21 to 35 & 58.5 & 53.2 & 52.6 & 87.8 & 75.8 & 91.5 & 6.7 & 10.4 \\
\hline 36 to 49 & 62.5 & 64.7 & 65.5 & 87.3 & 77.9 & 91.0 & 14.8 & 20.3 \\
\hline $\begin{array}{l}\text { Cramer's V } \\
\text { and p-value }\end{array}$ & $0.202 * * *$ & $0.297 * * *$ & $0.277 * * *$ & 0.013 & $0.032 * *$ & 0.010 & $0.171 * * *$ & $0.194 * * *$ \\
\hline \multicolumn{9}{|l|}{ Education } \\
\hline No education & 55.1 & 55.5 & 56.1 & 86.1 & 75.6 & 88.6 & 8.5 & 12.4 \\
\hline Primary & 53.5 & 54.6 & 52.5 & 86.4 & 73.6 & 89.7 & 8.0 & 11.5 \\
\hline Secondary & 55.6 & 46.7 & 47.5 & 88.4 & 75.2 & 93.6 & 9.0 & 12.3 \\
\hline Higher & 65.6 & 51.3 & 54.6 & 94.2 & 85.5 & 96.8 & 10.0 & 15.2 \\
\hline $\begin{array}{l}\text { Cramer's V } \\
\text { and p-value }\end{array}$ & $0.069 * * *$ & $0.077 * * *$ & $0.073 * * *$ & $0.076 * * *$ & $0.079 * * *$ & $0.102 * * *$ & 0.020 & $0.030^{*}$ \\
\hline \multicolumn{9}{|c|}{ Currently working } \\
\hline Not working & 52.1 & 46.0 & 49.6 & 86.9 & 75.2 & 89.5 & 9.4 & 12.7 \\
\hline Working & 58.8 & 56.3 & 54.8 & 88.3 & 76.9 & 92.3 & 8.3 & 12.5 \\
\hline $\begin{array}{l}\text { Cramer's V } \\
\text { and p-value }\end{array}$ & $0.066 * * *$ & $0.100 * * *$ & $0.051 * * *$ & $0.021^{*}$ & $0.020^{*}$ & $0.047 * * *$ & $0.020^{*}$ & 0.003 \\
\hline \multicolumn{9}{|c|}{ Types of residence } \\
\hline Urban & 59.4 & 55.5 & 56.5 & 88.1 & 76.5 & 92.0 & 10.5 & 14.2 \\
\hline Rural & 50.6 & 46.7 & 46.3 & 87.0 & 75.8 & 89.7 & 5.6 & 9.7 \\
\hline $\begin{array}{l}\text { Cramer's V } \\
\text { and p-value }\end{array}$ & $0.085 * * *$ & $0.084 * * *$ & $0.099 * * *$ & 0.017 & 0.008 & $0.039 * * *$ & $0.083 * * *$ & $0.065^{* * *}$ \\
\hline \multicolumn{9}{|l|}{ Province } \\
\hline Province1 & 68.1 & 60.5 & 68.3 & 87.7 & 78.4 & 92.9 & 13.9 & 17.6 \\
\hline Province2 & 53.7 & 46.2 & 50.6 & 85.2 & 74.5 & 84.3 & 8.7 & 14.8 \\
\hline Province3 & 64.2 & 59.6 & 64.5 & 88.4 & 77.4 & 95.0 & 9.6 & 16.0 \\
\hline Province4 & 64.7 & 59.3 & 56.7 & 92.1 & 79.2 & 96.5 & 10.5 & 14.5 \\
\hline Province5 & 51.4 & 47.3 & 48.3 & 88.1 & 77.3 & 90.4 & 6.8 & 11.4 \\
\hline Province6 & 44.1 & 47.1 & 34.9 & 87.7 & 76.0 & 93.0 & 8.0 & 9.2 \\
\hline Province7 & 50.6 & 50.1 & 49.7 & 86.1 & 71.8 & 89.3 & 4.0 & 4.5 \\
\hline $\begin{array}{l}\text { Cramer's V } \\
\text { and p-value }\end{array}$ & $0.164 * * *$ & $0.122 * * *$ & $0.204 * * *$ & $0.060 * * *$ & $0.054 * * *$ & $0.138 * * *$ & $0.100 * * *$ & $0.125^{* * *}$ \\
\hline \multicolumn{9}{|l|}{ Wealth index } \\
\hline Poorest & 48.9 & 49.3 & 45.5 & 88.4 & 77.3 & 92.6 & 2.8 & 5.1 \\
\hline Poorer & 53.7 & 49.4 & 49.5 & 87.5 & 75.0 & 91.9 & 6.2 & 9.3 \\
\hline Middle & 55.0 & 50.5 & 51.6 & 84.8 & 72.5 & 87.7 & 6.9 & 11.6 \\
\hline Richer & 58.2 & 51.7 & 53.9 & 87.4 & 77.0 & 90.5 & 9.9 & 16.2 \\
\hline Richest & 67.3 & 62.2 & 65.9 & 90.9 & 80.2 & 93.7 & 20.1 & 22.9 \\
\hline $\begin{array}{l}\text { Cramer's V } \\
\text { and p-value }\end{array}$ & $0.119 * * *$ & $0.092 * * *$ & $0.132 * * *$ & $0.058 * * *$ & $0.059 * * *$ & $0.073 * * *$ & $0.200 * * *$ & $0.179 * * *$ \\
\hline
\end{tabular}

Source: calculated from NDHS, 2016

Note: $*$ indicates $p<0.05, * *$ indicates $p<0.01$ and $* * *$ indicates $p<0.001$ 
Urban women are more likely to be empowered in the case of household decision-making and ownership of house/land. The relationship between variables of decision making and ownership of land/house is statistically significant with types of residence however the association is low. There is not much considerable difference between urban and rural women justifying wife-beating. Only 'wife argues with husband' is associated with types of residence.

Married women of province1 enjoy more decisive power than women residing in province4 who have a stronger attitude to reject wifebeating in comparison to other provinces. The $\mathrm{p}$-value for all the variables with provinces is significant but the association is weak. The increasing pattern of wealth strata enhances women's household decision making, and ownership of house/land additionally all the variables examined are statistically significant with wealth index.

Table 3: Employment status of married women by empowerment indicators

\begin{tabular}{lcccc}
\hline $\begin{array}{l}\text { Employment } \\
\text { status }\end{array}$ & \multicolumn{4}{l}{$\begin{array}{l}\text { Percentage of empowered married women based on } \\
\text { three indicators of empowerment }\end{array}$} \\
\cline { 2 - 5 } & $\begin{array}{l}\text { Household } \\
\text { decision- } \\
\text { making }\end{array}$ & $\begin{array}{l}\text { Attitudes } \\
\text { towards } \\
\text { wife-beating }\end{array}$ & $\begin{array}{l}\text { Ownership } \\
\text { of house/ } \\
\text { land }\end{array}$ & Total \\
\hline Not working & 31.7 & 70.7 & 17.6 & 3890 \\
Working & 38 & 73.5 & 16.1 & 6007 \\
Total & 35.5 & 72.4 & 16.7 & 9897 \\
Chi-square (1, & $41.370^{* * *}$ & $9.286^{* *}$ & 3.623 & \\
9897) & & & & \\
Cramer's V & $0.065^{* * *}$ & $0.031^{* *}$ & 0.019 & \\
\hline
\end{tabular}

Source: calculated from NDHS, 2016

Note: $*$ indicates $p<0.05, * *$ indicates $p<0.01$ and $* * *$ indicates $p<0.001$

Table 3 displays in the case of household decision-making, a larger number of working married women are empowered to decide on their own. Likewise, the majority of women (either employed or not employed) have not justified wife-beating. Moreover, women's employment status is statistically significant but a weak association with household decisionmaking and justifying attitudes towards wife-beating. It means that decisionmaking and attitude towards wife-beating; empowerment indicators are significantly dependent on the pattern of employment (the proportion of women employed or not employed). While contradictorily working 


\section{EMPLOYMENT EMPOWERING WOMEN: AN EXPERIENCE OF NEPAL}

married women have less ownership of house/land, and the linkup between women's employment status and ownership of house/land is independent (p-value $=0.057)$.

Table 4: Odds ratios for women's empowerment to different background characteristics

\begin{tabular}{|c|c|c|c|c|c|c|c|}
\hline \multicolumn{2}{|l|}{ Characteristics } & \multicolumn{2}{|c|}{$\begin{array}{c}\text { Household Decision- } \\
\text { making }\end{array}$} & \multicolumn{2}{|c|}{$\begin{array}{c}\text { Attitudes towards } \\
\text { wife-beating }\end{array}$} & \multicolumn{2}{|c|}{$\begin{array}{c}\text { Ownership of land or } \\
\text { house }\end{array}$} \\
\hline $\begin{array}{c}\text { Currently } \\
\text { working }\end{array}$ & $\begin{array}{l}\text { Not working } \\
\text { Working }\end{array}$ & $0.756^{* * *}$ & $0.748^{* * *}$ & $0.870^{* *}$ & $0.896^{*}$ & 1.110 & 0.978 \\
\hline \multirow{3}{*}{ Age } & Up to 20 (ref) & & & & & & \\
\hline & 21-35 & & $0.162 * * *$ & & $0.813^{* *}$ & & $0.053 * * *$ \\
\hline & $36-49$ & & $0.756^{* * *}$ & & $0.865^{* *}$ & & $0.382 * * *$ \\
\hline \multirow[t]{5}{*}{ Education } & Illiterate (ref.) & & & & & & \\
\hline & Primary & & 1.055 & & & & 0.870 \\
\hline & & & & & $0.499 * * *$ & & \\
\hline & Secondary & & 1.124 & & $0.434 * * *$ & & 0.934 \\
\hline & Higher & & 1.031 & & $0.518^{* * *}$ & & 1.099 \\
\hline \multirow{2}{*}{$\begin{array}{c}\text { Types of } \\
\text { residence }\end{array}$} & Urban (ref.) & & & & & & \\
\hline & Rural & & $1.295^{* * *}$ & & 1.033 & & 1.099 \\
\hline \multirow[t]{7}{*}{ Province } & Province1 & & & & & & \\
\hline & Province2 & & $2.007 * * *$ & & $1.437 * * *$ & & $4.045^{* * *}$ \\
\hline & Province3 & & $1.527 * * *$ & & $1.272 * *$ & & $3.102 * * *$ \\
\hline & Province4 & & $1.437 * * *$ & & $1.349 * * *$ & & $2.457 * * *$ \\
\hline & Province5 & & $1.520^{* * *}$ & & $1.605^{* * *}$ & & $2.771 * * *$ \\
\hline & Province6 & & 0.974 & & $1.420 * * *$ & & $2.011^{* * *}$ \\
\hline & Province7 & & 0.650 *** & & $1.194 *$ & & $3.246^{* * *}$ \\
\hline \multirow[t]{5}{*}{ Wealth } & Poorest (ref) & & & & & & \\
\hline & Poorer & & $0.726^{* * *}$ & & 1.070 & & $0.138 * * *$ \\
\hline & Middle & & $0.668^{* * *}$ & & 0.875 & & $0.309 * * *$ \\
\hline & Richer & & $0.755^{* * *}$ & & $0.753^{* * *}$ & & $0.363 * * *$ \\
\hline & Richest & & $0.850^{*}$ & & 0.919 & & $0.587 * * *$ \\
\hline Constant & & $0.613^{* * * *}$ & $0.701^{* *}$ & $2.780^{* * * *}$ & $4.646^{* * *}$ & $0.192 * * *$ & $0.344^{* * *}$ \\
\hline$-2 L L$ & & 12835.95 & 11932.23 & 11643.27 & 11592.83 & 8916.41 & 7611.35 \\
\hline Negelkerke $R^{2}$ & & 0.006 & 0.125 & 0.001 & 0.024 & 0.001 & 0.209 \\
\hline
\end{tabular}

Note: Here ref $=$ reference category and $*$ indicates $p<0.05$, ** indicates $p<0.01$ and $* * *$ indicates $p<0.001$

Table 4 depicts if not controlled for other variables regression outcome for decision-making and attitudes towards wife-beating with a working status of married women is statistically significant. Working married women has lesser odds for household decision-making and attitudes towards wife-beating (0.756 and 0.870 respectively) in comparison to not working women. After controlling for other study variables, household decision-making and attitudes towards wife-beating remains statistically 
significant for the employment status of married women. Similarly, after controlling other study variables, regression results confirm a significant effect of women's background characteristics namely currently working status, age, education, types of residence, province, and wealth to explain women's household decision-making, attitudes towards wife-beating, and ownership of house/land. All three empowerment indicators decrease with growing older. Inline, education has no statistically significant effect on women's household decision-making and ownership of house/land. But the odds ratios of education for attitudes towards wife-beating of women decrease with one unit plus in reference group; illiterates. It implies that the probability of justifying attitudes towards wife-beating lowers for educated women.

For an additional unit in urban, the odd of decision-making of rural multiplies by 29.5 percent $(1.295 * 100-100)$. In the same way, the probability of decision-making occurring with a unit increase in provincel higher than at the original value of all, however, this inversely relates to province7. Identically, a unit plus in reference category i.e. provincel augments attitudes towards wife-beating of rest provinces. The odds of ownership of house/land are more likely to accelerate for remaining provinces (4 times for province 2, 3 times for province 3, 2 times for province 4, 2 times for province 5, 2 times for province6, 3 times for province 7) regarding province1. There are significantly declining odds ratios with increasing household wealth index, with all ratios less than unity, showing a clear negative relationship of women's household decision-making and ownership of house/land with their employment status. A poorer compared to the poorest is 0.726 and 0.138 times less likely to have household decision-making power and ownership of land/house respectively.

\section{DISCUSSION}

The findings of the study suggest that women's employment enhances their empowerment, but also adds new insight into this complex relationship. Doubtlessly, socio-demographic variables are found to be associated with women's working status but the statistical tests show the moderate relationship of empowerment with wealth and province. In the case of other variables, the tests show a weak relationship with empowerment. Several working women's hikes with their maturing age are similarly reflected in the results of Khan (2016). As the wealth index goes 
up women's working status falls, Khan (2016) had identical findings for Bangladesh but contradicts with Pambe (2014). More illiterate and rural women are working than educated with any other education level and urban women identically in the study of Khan (2016) and Phan (2015). Biswas (2016) discusses the reason that women severely suffering from poverty and less qualification are bound to infringe the socio-cultural protocol and to seek opportunities in the labour market. The study shows a few working women have ownership of house/land, surprisingly control over the real estate is even rarer, the similar findings in Basnet (2014) study. The ownership of house/land promotes the empowerment of women (Mishra \& Sam 2016, Valera et al. 2018). Nepalese social and cultural practices, feeble governance, acute poverty, and illiteracy rates barricade women's access to properties on their names (Basnet 2014). Alone employment is not sufficient to empower the subordinate category.

Among eight variables of empowerment belonging to three empowerment indicators (decision-making, the justification for wifebeating, and ownership of land or house) are found to be significant (except owns land alone or jointly) but weak association. Married women have low mobility, lower decision-making, and justification for wife-beating concerning other types of marital status (West 2006). The justification of domestic violence has a significant but remarkable inverse relationship with women's employment status contradict the findings of Boateng et al., (2012). Alike in a work by Ebrahim \& Atteraya (2017), married women have favorable attitudes towards domestic violence in any given case. The probable reason behind this could be the embedded patriarchal social norms and teachings transmitted to women by the society, is to comply and carry on their livelihood under the custody of their husbands (Biswas 2016) and wife-beating is the inborn right of husband (Jejeebhoy 1998, Alam 2018). The finding of the study reveals that the employment of married women does not add decisive power in the household (Pambè \& Thiombiano 2014, West 2006), this could be because of the subordinated role of women in Nepalese society. Ebrahim (2017) admitted that higher autonomy in decision-making could serve as robust changed attitudes towards wife-beating. The study has exhibited an insignificant relationship between women's employment and ownership of house/land. Basnet (2012) has also found that ownership of land is rarely leading to women's control of the very resource. 
Irrespective of whether the variables are controlled or not, household decision-making and attitudes towards wife-beating worsens for working women in line with West (2006). The probable scenario is women are tolerating violence as a trade-off for elevating by breaking down the social norms and barriers of going outside of four walls (West 2006).

All three indicators of empowerment relatively fall as married women get older. Similarly, Valera et al. (2018) also extract that with the maturing age of Indian women's household decision-making declines, however, Acharya et al. (2010), Boateng (2012) and West (2006) do not result in the same. Pambè \& Thiombiano (2014) also do not found age as a prominent variable for household decision making. The probable reason could be younger women may have innovative and updated knowledge with higher education, and are technically sound too, which may be causing the family to trust their knowledge.

Attitudes towards wife-beating decrease with married women's higher level of education which contradicts Alam (2018). Acharya et.al. (2010), Boateng (2012), Phan (2015), and West (2006) have shown higher education leading higher decisive power notwithstanding this study comes with a similar result but insignificant association. Educational attainment does not play a significant role to empower women (Pambè \& Thiombiano 2014) to mitigate domestic violence. Rural married women are significantly more likely to be empowered for household decision-making as compared to urban women in line with Pambe (2014) but not with West (2006) and Boateng (2012).

Household decision-making, attitudes towards wife-beating, and ownership of house/land nearly increase more than one time (except province 7 for decision making) for all seven provinces in comparison to province1. Decision-making power is found to be low as compared to the eastern region, the result of Acharya (2010) is near identical to this study that women of provincel are autonomous to decide on their own compared to province7. Discernably, Province7 is the state where even today 'Chaupadi' tradition (banishment of women during menstruation) is accepted and followed too. Provinces are studied very little by the time because the provincial system is recently introduced to the country hence further detailed studies are needed to carry on. 
Women's household decision-making and ownership of house/ land relatively drop with women's closeness to a better level wealth index. Similarly, Acharya, et al. (2010) has also admitted the same for decision making in Nepal (Ebrahim \& Atteraya 2017) but the result of Boateng (2012) contradict regarding decision-making power but Mishra and Sam (2015) are in line with the result for women's ownership of land. Identically, in a study of Pakistan, wealth is not likely to influence wife-beating justification. The grounded cultural practices rather than socio-economic phenomena may be partly can explain the scenario of Pakistan.

\section{CONCLUSIONS}

The study aims to measure the relationship between the employment and empowerment of women and to examine the association of empowerment with socio-demographic characteristics. Outcomes of the study are employment empowers women on their decision-making and attitudes towards wife-beating. Age, province, and wealth index of women significantly affect their empowerment.

In the context of Nepal, women's dependent mobility, poor decisive power, limited control over resources and massive acceptance of wife-beating practices prevails, employment could be a mere piece of the puzzle to win the game of empowering women. Without the radical changes in the running patriarchal system and mindset of society for women as a subordinated category, employment, economic openness, education, leadership, and many more may not be able to reform and uplift the status of women. Due to the urban and rural residence, education level, and financial status of women also cause their empowerment through regular uplifting the status of women in Nepal cannot be overlooked. Women's participation in the labour market is indispensable and a win-win strategy, not just to empower women rather strengthen families, organizations, and society even more for a drastic change in the global context.

\section{REFERENCES}

Acharya, D. R., Bell, J. S., Simkhada, P., Teijlingen, E. R. Van, \& Regmi, P. R. (2010). Women's autonomy in household decision-making: a demographic study in Nepal, (1), 1-12. 
Acharya, M. \& Bennett, L. (1983). Women and the subsistence sector: Economic participation and household decision-making in Nepal. Working Paper Number 526. Washington: World Bank.

Alam, S., Tareque, I., Peet, E. D., Rahman, M., \& Mahmud, T. (2018). Female participation in household decision making and the justification of wife beating in Bangladesh. Journal of Interpersonal Violence, 36(7-8): 2986-3005. https://doi.org/10.1177/0886260518772111

Atteraya, M. S., Gnawali, S., \& Women, P. E. (2016). Women's participation in self-help groups as a pathway to women's empowerment : A case of Nepal, International Journal of Social Welfare, 25(4): 1-10. https://doi.org/10.1111/ijsw.12212

Basnet, S. (2014). Women's land ownership and empowerment: A case study of Mrigauliya Village Development Committee Master of Arts in Inter-Asia NGO studies Master's Degree Thesis https://doi. org/10.13140/2.1.3569.6008

Batliwala, S. (1993). Empowerment of women in South Asia: Concepts and Practices. New Dehli

Berniell, M., \& Sánchez-Páramo, C. (2011). Overview of time use data used for the analysis of gender differences in time use patterns. Background paper for the World Development Report (2012), World Bank, Washington, DC.

Bisnath, S. (2001). Poverty in a globalizing world at different stages of women's life cycle globalization, poverty, and women's empowerment. United Nations Division for the advancement of Women $(D A W)$. New Delhi, India.

Biswas, C. S. (2016). Spousal violence against working women in India. Journal of Family Violence, 32: 55-67, https://doi.org/10.1007/ s10896-016-9889-9

Boateng, G. O., Kuuire, V. Z., Ung, M., Amoyaw, J. A., Armah, F. A., \& Luginaah, I. (2012). Women's empowerment in the context of Millennium Development Goal 3 : A case study of married women. Social Indicators Research, 115: 137-158, https://doi.org/10.1007/ s11205-012-0212-8

Braunstein, E. (2008). Women's employment, empowerment, and globalization: An economic perspective. New York: UN. 


\section{EMPLOYMENT EMPOWERING WOMEN: AN EXPERIENCE OF NEPAL}

Calvès, A. E. (2009). Empowerment: The history of a key concept in contemporary development discourse. Revue Tiers Monde, 4: 735749.

Chowdhury, S. R., Bohara, A. K., \& Horn, B. P. (2018). Balance of power, domestic violence, and health injuries : Evidence from Demographic and Health Survey of Nepal. World Development, 102: 18-29. https://doi.org/10.1016/j.worlddev.2017.09.009

Diallo, S. A., \& Ã, M. V. (2016). The threat of domestic violence and women wmpowerment : The case of West Africa, 28(1): 92-103.

Duflo, E. (2012). Women empowerment and economic development. Journal of Economic Literature. 50(4): 1051-1079. http://dx.doi. org/10.1257/jel.50.4.1051.

Ebrahim, N. B., \& Atteraya, M. S. (2017). Women's Decision-Making Autonomy and their Attitude towards Wife-Beating: Findings from the 2011 Ethiopia's Demographic and Health Survey. Journal of Immigrant and Minority Health, 20: 603-611. https://doi. org/10.1007/s10903-017-0592-6

Hanmer, L., \& Klugman, J. (2016). Exploring women's agency and empowerment in developing countries: Where do we stand?, 5701(February). Feminist Economics, 22(1): 237-263. https://doi. org/10.1080/13545701.2015.1091087

IFC. (2013). The power of partnership. International Finance Corporation. https:/www.ifc.org/wps/wcm/connect/61766bbb8986-451b-9ca4-57a9466f4e81/AR2013_Full_Report. pdf?MOD=AJPERES\&CVID=k5ruszm

Jejeebhoy, S. (2000). Women's autonomy in rural India: Its dimensions, determinants, and the influence of context. In: Presser HB \& Sen G. (eds.) Women's empowerment and demographic processes: Moving beyond Cairo 1st edition. New York: Oxford University Press.

Kabeer, N. (2005). Gender equality and women's empowerment: A critical analysis of the third-millennium development goal 1. Gender \& Development, 13(1), 13-24.

Khan, M. (2016). Socio-economic empowerment of women in Pakistan; Evidence from Gilgit-Baltistan. International Journal of Asian Social Science, 6(8), 462-471. 
Kishor, S. (2000). Empowerment of women in Egypt and links to the survival and health of their infants. In: Presser, H. and Sen, G. (eds.) Women's empowerment and demographic processes: Moving beyond Cairo. New York: Oxford University Press.

Mason, K. O. \& Smith, H. L. (2003). Women's empowerment and social context: Results from five Asian countries. Washington, D.C.: The World Bank.

Mishra, K., \& Sam, A. G. (2016). Does women's land ownership promote their empowerment? Empirical evidence from Nepal, World Development, 78: 360-371. https://doi.org/10.1016/j. worlddev.2015.10.003

Mueller, D.R. (1998). Female empowerment and demographic processes: Moving beyond Cairo. International Union for the Scientific Study of Population.

NRNA \& UN. (2014). NRNA and UN Women to promote gender equality and women's empowerment. [Press Release].

OECD. (2012). Women's economic empowerment. Poverty reduction and pro-poor growth, Organization for Economic Cooperation Development.

Pambè, M. W., \& Thiombiano, B. G. (2014). Relationship between women's socioeconomic status and empowerment in Burkina Faso : A focus on participation in decision-making and experience of domestic violence, 28(2): 1146-1156.

Phan, L. (2015). Measuring women's empowerment at household level using DHS data of four Southeast Asian Countries. Social Indicators Research 126: 359-378. https://doi.org/10.1007/s11205015-0876-y

Rowland, J. (1997). Questioning empowerment. Oxford: Oxfam Publication.

AF. (2009). A year of action. The Asia Foundation. https://asiafoundation. org/resources/pdfs/AnnualReport09lowres.pdf

UNESCAP (1999). Emerging issues and developments at the regional level: Socio-economic measures to alleviate poverty in rural and urban areas. E/ESCAP/1133. 
Valera, H. G. A., Yamano, T., Puskur, R., Veettil, P. C., \& Valer, H. G. A. (2018). Women's land title ownership and empowerment : evidence from India ADB economics working paper series (559).

West, B. S. (2006). Does employment empower women? An analysis of employment and women's empowerment in India. (Master's Thesis), Cornell University

White, H. \& Killick, T. (2001). African poverty at the millennium: Causes, complexities, and challenges. Washington, D.C: The World Bank. 